\title{
Transdisciplinary research and stakeholder involvement. A review of the TFO approach.
}

\author{
Laura Schmidt, Stephanie Domptail, Martin Gruber, Patrick Klintenberg, Ute \\ Schmiedel, Ibo Zimmermann \& Thomas Falk
}

\begin{abstract}
The challenges faced in times of global change require new ways of knowledge production in order to understand the dynamics arising from complex social-ecological systems and to support people's decision making. Integrative approaches are demanded that incorporate a wide range of bodies of knowledge for joint problem-solving amongst scientists and stakeholders. In this context, transdisciplinary research approaches have received growing attention to address these real-world problems and to bridge the gap between scientific knowledge production and decision making. While promising in its ideal-typical conception, experience-based guidelines of how to implement transdisciplinary research are rare. In this paper we aim to present and analyze the approaches applied to involve stakeholders in the research activities in the case of The Future Okavango (TFO) project. Based on a distinction of four levels of intensity for stakeholder involvement, we present the instruments selected to address the diverse stakeholders in the Okavango Basin in the course of the research process. By discussing the role and contribution of these approaches for the overall objectives of the project and by highlighting the challenges faced, we aim to give insight into TFO's experiences and guidance for the planning of future transdisciplinary research projects. Concluding remarks on the lessons learnt aim to trigger processes of reflection on transdisciplinarity in general as well as on the approach of the TFO project.
\end{abstract}

Keywords: Decision support; integrative research; natural resource management; Okavango River Basin; participation; project design; Southern Africa; science-policy interface; transdisciplinarity.

A pesquisa transdisciplinar e o envolvimento das partes interessadas. Uma revisão da abordagem TFO.

Resumo: Os desafios enfrentados em tempos de mudança global requerem novas formas de produção de conhecimento, a fim de compreender a dinâmica decorrente dos complexos sistemas sócio-ecológicos e para apoiar a tomada de decisão das pessoas. São necessárias abordagens integradoras, que incorporem uma grande variedade de campos de conhecimento, para a resolução conjunta de problemas entre cientistas e partes interessadas. Nesse contexto, as abordagens transdisciplinares de pesquisa têm recebido crescente atenção, a fim de resolver esses problemas do mundo real e fazer a ponte entre a produção de conhecimento científico e a tomada de decisão. Embora promissora em sua concepção típica ideal, diretrizes baseadas em experiências de como implementar a pesquisa transdisciplinar são raras. Neste artigo pretendemos apresentar e analisar as abordagens aplicadas para envolver as partes interessadas nas atividades de pesquisa no caso do projeto "The Future Okavango" (TFO). Com base em uma distinção de quatro níveis de intensidade para a sua participação,, apresentamos os instrumentos selecionados para abordar as diversas partes interessadas na bacia do Okavango, no decorrer do processo de pesquisa. Ao discutir o papel e a contribuição dessas abordagens para os objetivos gerais do projeto e destacando os desafios enfrentados, pretendemos dar uma visão sobre as experiências do TFO e orientação para o planejamento de futuros projetos de pesquisa transdisciplinar. Observações finais sobre as lições aprendidas visam desencadear processos de reflexão sobre a transdisciplinaridade em geral, bem como sobre a abordagem do projeto TFO.

Palavras-chave: apoio à decisão; design de projeto; gestão de recursos naturais; interface da ciência-política; Okavango; participação; pesquisa integrativa; transdisciplinaridade; Sul da África.

Received: 27 September 2013 -Accepted: 19 December 2013

\section{Introduction}

Fast and complex global changes with uncertain outcomes such as climate change, population growth, globalisation, and land degradation require sophisticated adaptations of policy and decision making. Man strongly shapes ecosystems and at the same time depends on its functions and services. The emerging need to understand and address these complex dynamics resulting from the interactions between the human and ecological systems leads to a changing role of science in society. Policies based on the acknowledgment of complexity need to be informed by an integrative science which incorporates a wide range of bodies of knowledge (Jahn 2008, Mogalle 2001, Spangenberg 2011, Reyers et al. 2010, MEA 2005, TEEB 2010).

In this context, the concepts of transdisciplinary research attract growing attention in the academic but also the political world (Hirsch Hadorn et al. 2006, Scholz \& Tietje 2002, Maasen \& Lieven 2006). Even though no common definition of transdisciplinarity exists, it generally refers to an integrated research approach involving multiple disciplines as well as non-scientific stakeholders that are defined by the shared problem to be addressed (Pohl \& Hirsch Hadorn 2007; Lang et al. 2012; Mogalle 2001; Bergmann et al. 2005; Häberli \& Grossenbacher-Mansuy 1998). In this paper we make reference to Klein et al. (2001) who define transdisciplinary research as a process where different academic disciplines work jointly with practitioners to solve real-world problems. 
The idea of science for society through one-way information flows from scientists to the public is being replaced by the notion of science with society, which triggers a process of reciprocal learning (Scholz 2011, Spangenberg 2011, Stauffacher et al. 2008). The active involvement of stakeholders in transdisciplinary research projects is inherent (Moll \& Zander 2006). Nevertheless, several key issues need to be clarified to ensure added benefit. Who should be involved at what research phase for what objective and hence by which means and to what degree of entitled power? To address the particular objectives of the transdisciplinary research, stakeholder involvement needs to be designed in a flexible but targetoriented way with tailored techniques (Stauffacher et al. 2008, Krütli et al. 2010).

The paper shows how the involvement of non-scientific stakeholders can be achieved in the context of a large-scale research project, based on the case of The Future Okavango (TFO) project as it studies a complex social-ecological system, has the objective to produce knowledge relevant for decision and policy makers, and commits itself to integrate a transdisciplinary approach into its research process. The paper presents and analyses the different approaches for stakeholder involvement of TFO using the typology of stakeholder involvement developed by Stauffacher et al. (2008). It aims at assessing the role and contribution of current methods for stakeholder involvement to the overall aims of the project in the first place and, in addition, gives recommendations for future involvement strategies. Looking at the case of TFO also shows the ambivalence between the potentials and scientific (new) benefits of transdisciplinary processes on the one hand and the high complexity and constraints faced when doing transdisciplinary research "in vivo" on the other.

The next section starts with a review of the literature on transdisciplinarity, provides an outline of the core arguments for stakeholder involvement in transdisciplinary research and finally introduces the typology for stakeholder involvement used in this paper. In section three, we picture the case of The Future Okavango project from a transdisciplinary perspective and present the different approaches applied to involve relevant stakeholders in the countries of Angola, Botswana and Namibia. In the fourth section, we highlight the lessons learnt and constraints faced regarding the involvement of stakeholders in research and put this into a broader context of challenges in the practice of transdisciplinarity. We then discuss the role and contribution of the approaches for the generation of knowledge, analyze achievements and shortcomings of TFO's stakeholder involvement and finally point to possibilities of adaptation for the remainder of the project as well as for the design of future projects.

\section{Stakeholder involvement in transdisciplinary research}

\section{The concepts of transdisciplinary research}

The steering of complex social-ecological systems towards sustainable pathways requires policies and decision making which takes into account the interactions between the features of the system. As a consequence, scientific support needs to acknowledge this complexity and assess management challenges in an integrated, rather than disciplinary, specialised, and isolated way. With regard to this sciencepolicy interface, the discourse on transdisciplinary research has become increasingly dynamic especially in the context of the debate on sustainable development emerging from the UN Earth Summit in Rio de Janeiro 1992 (Häberli \& Grossenbacher-Mansuy 1998, Mogalle 2001, Dubielzig \& Schaltegger 2004, Siew \& Döll 2012, Brandt et al. 2013).

Even though a consistent paradigm or shared research framework remains outstanding, a number of aspects commonly characterise the transdisciplinary approach in a diversity of studies. It commonly addresses problems from the real world, integrates various disciplines as well as nonscientific stakeholders in order to enable processes of joint knowledge generation and mutual learning and finally aims to create solution-oriented and practical relevant knowledge (see e.g. Pohl \& Hirsch Hadorn 2007, Lang et al. 2012, Bergmann et al. 2005, Mogalle 2001, Häberli \& Grossenbacher-Mansuy 1998).

Integration - of knowledge and methods between scientific disciplines in terms of interdisciplinarity on the one hand as well as of tacit and experiencebased knowledge of non-scientific stakeholders on the other hand - is a core feature of transdisciplinary research (Jahn et al. 2012). It results in synergies as the merging of different types of academic, tacit and experience-based knowledge leads to knowledge production that goes beyond the aggregated sum of the individual bodies of knowledge (Dubielzig \& Schaltegger 2004, Häberli \& Grossenbacher-Mansuy 1998, Mobjörk 2010, Maasen \& Lieven 2006). Integration in transdisciplinary research, however, does not only refer to the cognitive dimension. It also implies aspects of social, organisational and communicative integration between the scientists and practitioners involved and thus increases the challenge of transdisciplinarity (Jahn 2008, Jahn et al. 2012, Klein 2008).

\section{Objectives of stakeholder involvement}

The close interaction and integration between scientific and practical bodies of knowledge in the course of the research project ensures the generation of socalled socially robust knowledge, being not only scientifically valuable but also practically relevant for stakeholders' actions and decisions to cope with the problem (Klein et al. 2001, Maasen \& Lieven 2006). Transdisciplinary approaches therefore need to be designed in a way to enable processes of mutual learning and knowledge generation between the different understandings in science and society but also within these groups (Collins \& Ison 2009, Mobjörk 2010)

Referring to the characteristics of transdisciplinarity in addressing realworld problems with the aim of solution finding, transdisciplinary research commonly deals not only with analysing the state of the particular system observed (system knowledge) but is also confronted with questions about what goal or solution is aimed for (target knowledge) and how this goal can be reached (transformation knowledge) (Fig. 1) (Pohl \& Hirsch Hadorn 2007, Jahn et al. 2012, Dubielzig \& Schaltegger 2004). As the construction of these types of knowledge is closely linked to stakeholders' values, norms, visions, interests, regulations, capacity and power relations, the understanding and integration of these aspects is of high relevance in order to bridge the often 


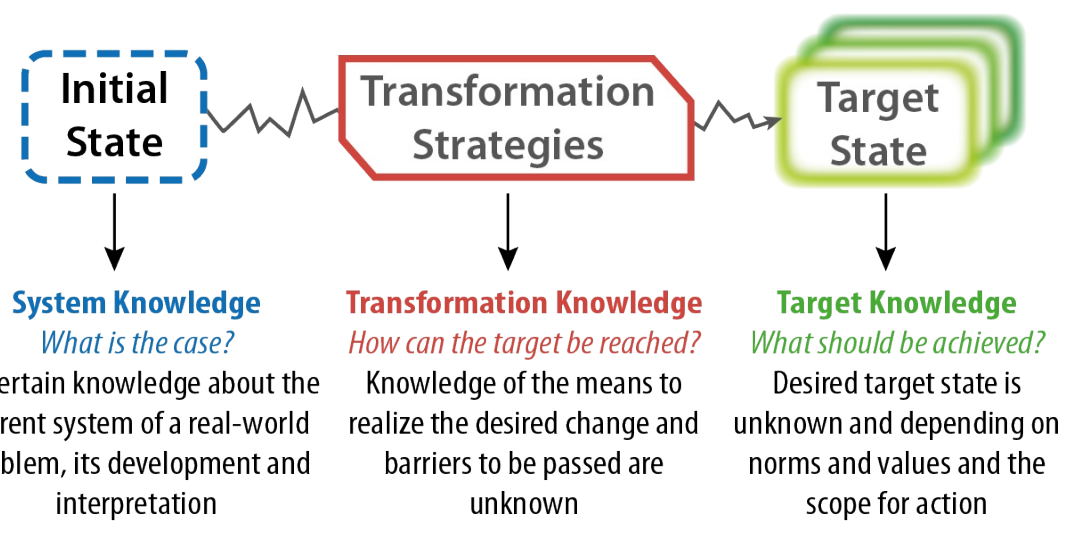

Fig. 1: Knowledge types in transdisciplinary research (adapted from Scholz \& Tietje 2002; Pohl \& Hirsch Hadorn 2007).

criticised gap between science and practice (Pohl \& Hirsch Hadorn 2007, Maasen \& Lieven 2006, Mobjörk 2010, Roux et al. 2006).

Finally, the active involvement of stakeholders in the research process fosters the legitimacy and ownership of research outcomes and hence can increase the motivation, empowerment and likelihood of stakeholders initiating and contributing to transformation and decision-making processes (Lang et al. 2012, Stauffacher et al. 2008, Enengel et al. 2012, Hirsch Hadorn et al. 2006).

\section{Levels of stakeholder involvement}

Addressing the objectives of transdisciplinary research requires adjusted forms of stakeholder involvement (Krütli et al. 2010). To avoid overstraining researchers and stakeholders due to excessive involvement, the specific forms need to be selected wisely, depending on the phase and goal of each respective research process. Stauffacher et al. (2008) propose a dynamic approach with a flexible variety of techniques providing different forms and intensities of involvement. To guide the decision on the techniques to use in the process, issues like why and when should who be involved on what aspects, and along with it, the expected effects of the techniques, need to be clearly formulated (Krütli et al. 2010, Stauffacher et al. 2008).

To present and discuss the techniques applied in the case study, we make use of the typology proposed by Stauffacher et al. (2008) and adapted by Krütli et al. (2010) for decision-making processes which differentiates between the various forms of involvement (similar typologies are information, consultation, collaboration and empowerment (Fig. 2) (Krütli et al. 2010).

The first two levels refer to forms of one-way communication with only a limited degree of commitments or power for stakeholders to actively influence the process. The first level, 'information', merely consists of communicating the objective, progress or outcome of research activities to stakeholders orally, visually or in writing. The second, 'consultation', aims at collecting knowledge, perceptions, suggestions or any other information from the stakeholder usually inquired through talks, interviews or questionnaires. Although this exchange is not binding, a weak form of cooperation exists as scientists have the intention to take the information gained into account while stakeholders have the feeling that they influence the process by articulating their knowledge and perceptions. The third level, 'collaboration', refers to a higher intensity of involvement including more interactive, two-way communication with stakeholders holding notable power on the research process and outcome. This also implies a higher degree of commitment including binding rules and competences. While the former, from our commitment and power relations between the parties. These levels of involvement

discussed and adapted for transdisciplinary research e.g. see Brand al. (2013), Tress et al. (2006), Enenge ive (2012)). Based on the distincti classifies involvement by the growi upwards her "ladder of citizen participation", four levels of involvement are discriminated, characterised by the varying degree of information flow,

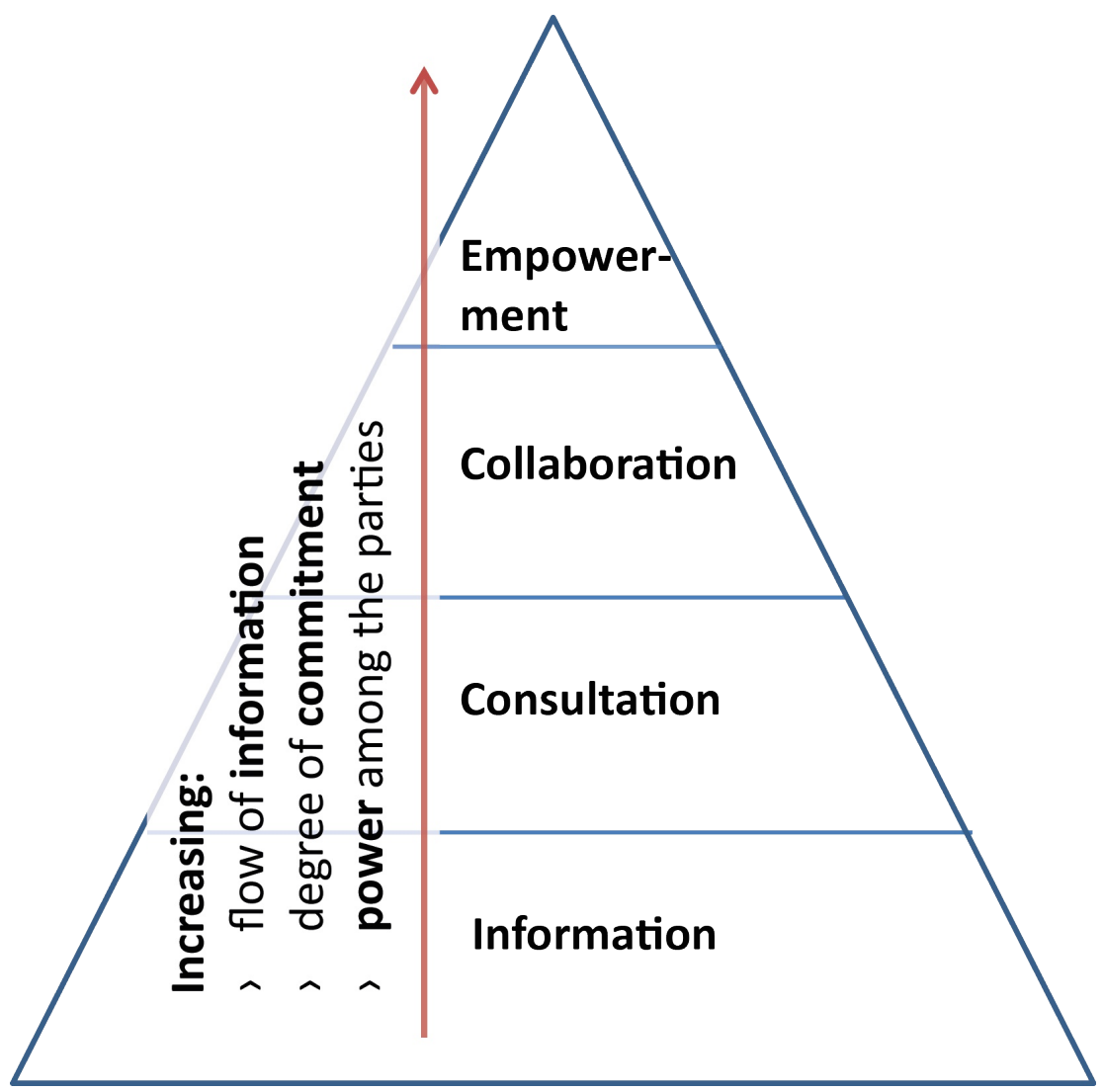

Fig. 2: The four levels of stakeholder involvement (adapted from Tress et al. 2006). 
understanding, still entails a hierarchical gap between the researchers and stakeholders involved on influencing the research process, the last level, 'empowerment', comprises the highest degree of intensity of involvement. By assigning equal rights or even authority in decision-making processes to stakeholders, these collaborating partners are empowered to determine the content and outcomes of the research process (Krütli et al. 2010, Stauffacher et al. 2008). With higher intensity of involvement however, aspects of legitimacy and power asymmetries increasingly manifest. Existing interest conflicts and power relations between stakeholders, their possibilities to become involved as well as their relationship to researchers need to be acknowledged (Krütli et al. 2010, Mobjörk 2010).

The choice of the level of stakeholder involvement depends on the objective of the particular engagement. The different techniques selected accordingly cannot be suitable for all research phases and stakeholders involved, but need to be applied and combined after their specific strength in order to achieve highest synergies. In the following section, we will present the different approaches selected and applied to involve stakeholders in The Future Okavango project with reference to their varying level of involvement and their potential to trigger processes of mutual learning.

\section{The case of The Future Okavango - presentation from a transdisciplinary perspective}

\section{Introduction to The Future Okavango project}

The Okavango River - with its source in the Angolan highlands, running along the northern border of Namibia and finally terminating in the world's largest inland Delta in the Kalahari Desert of Botswana (Fig. 3) - is of crucial importance not only for the region's ecology but also for people's livelihoods (Kghati et al. 2006, Mendelsohn \& el Obeid 2004). The ecosystems of the basin are in nearly pristine condition at present (Stellmes et al. 2013), however are increasingly experiencing rapid transformation processes (Hansen et al. 2013), driven by, inter alia, climate change with an increase in temperature since the late $70 \mathrm{~s}$ (see

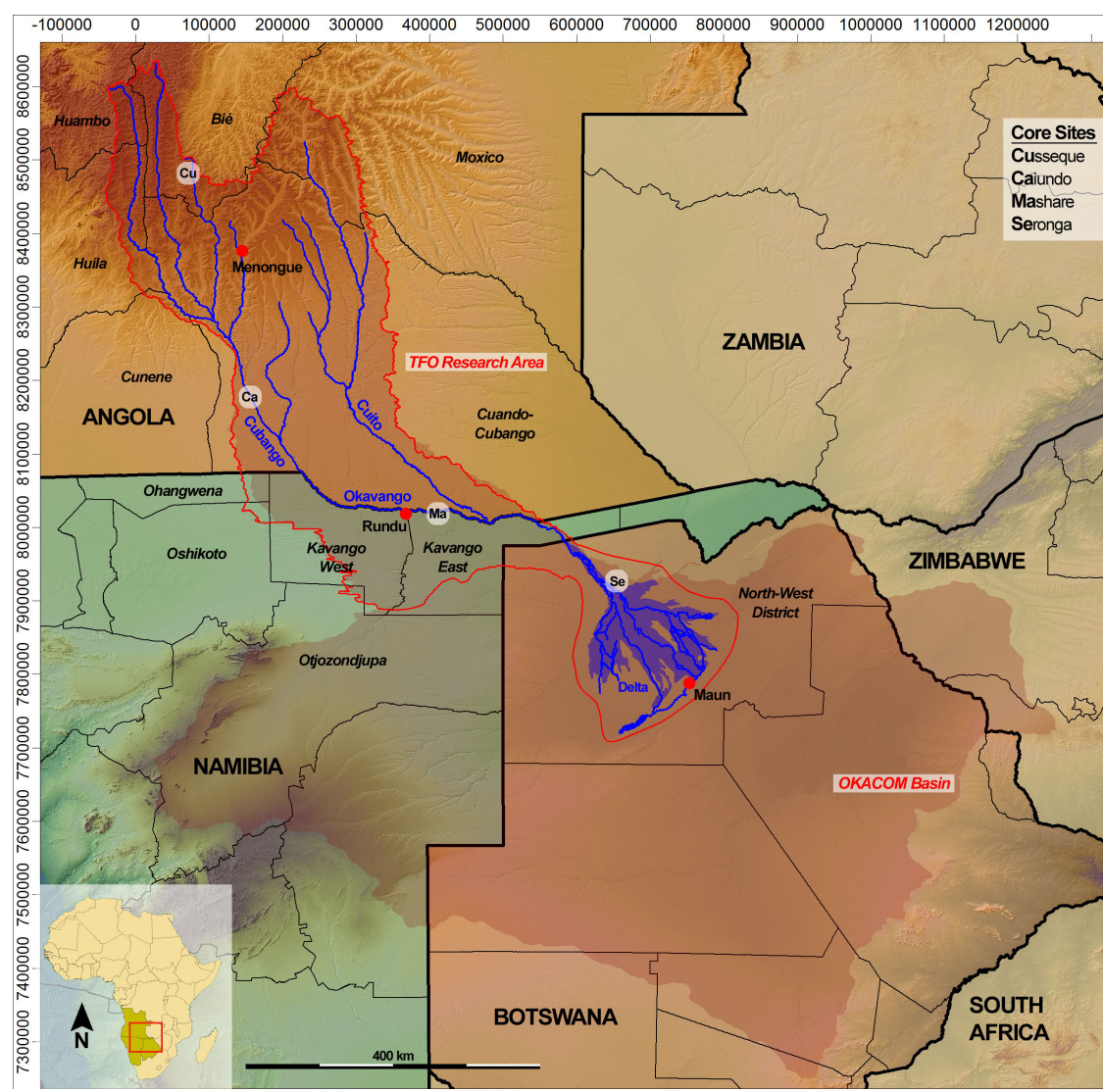

Fig. 3: The Okavango River Basin and the four levels of TFO's involvement: local (core site), provincial, national, and transboundary.

Weber 2013) agricultural expansion and overexploitation of natural resources linked to human population growth (Schneibel et al. 2013, Kghati et al. 2006, Mendelsohn \& el Obeid 2004, Hansen et al. 2013) as well as processes of globalisation, like agro-industrial foreign investments (Kghati et al. 2006) and the advent of consumerism, (Pröpper et al. 2013). These developments threaten to turn the transboundary basin into a global hot-spot of irreversible change, environmental degradation, biodiversity loss and potential conflicts on land and water use (Kghati et al. 2006, Mbaiwa 2004, Turton et al. 2003). The research project The Future Okavango (TFO) addresses this real-world problem, by analysing the interactions between land use patterns, ecosystem services and well-being within the Okavango River catchment. The project's objective is to provide socially-robust knowledge in order to support decision making for sustainable land use in the future through a transdisciplinary research approach (Seidel et al. 2012).

To meet the complexity of the problem, a wide range of scientists from various disciplines are involved in the research project coming from universities and research institutes in Germany, Angola, Botswana and Namibia. The interdisciplinary team includes scientists from hydrology and biology up to economists and anthropologists, being organised in ten subprojects. Regular workshops, thematic bi- and multilateral cooperation, a comprehensive website including an internal area as well as the specifically established platform for data and information management OBIS (Okavango Basin Information System; see Kralisch et al. 2013) facilitate the internal scientific communication and interplay. The concept of Ecosystem Functions and Services (ESF/ESS) builds the main framework for integrating the data and knowledge from the ecological, socio-cultural and economic analysis (Seidel et al. 2012). There is the need to consider the context of transboundary water management issues as well as the linkages of local and catchment scales and their interrelations. The latter is taken up in the core site approach with four selected local areas (Cusseque and Caiundo in Angola, Mashare in Namibia and Seronga in Botswana) for detailed studies on the ground that allows upscaling processes to the catchment level (Röder et al. 2013; Fig. 3). 
Table 1: Number of stakeholders (SH) identified in Angola (ANG), Namibia (NAM) and Botswana (BW) in each sector or stakeholder group, and the ranking of these sectors according to the score of each stakeholder of the sector for the prioritisation criteria (1)-(4) (only scores 'strong' and 'very strong' were added up) (adapted from Falk et al. 2012).

\begin{tabular}{|c|c|c|c|c|c|c|c|c|}
\hline \multirow[t]{2}{*}{ Sector } & \multicolumn{4}{|c|}{ Number of SH identified } & \multicolumn{4}{|c|}{ Criteria for prioritisation } \\
\hline & ANG & NAM & BW & total & $\begin{array}{l}\text { (1) SH impact } \\
\text { management }\end{array}$ & $\begin{array}{l}\text { (2) SH is affected } \\
\text { by ESS provision }\end{array}$ & $\begin{array}{l}\text { (3) SH impact } \\
\text { TFO project }\end{array}$ & $\begin{array}{l}\text { (4) SH is affected } \\
\text { by TFO project }\end{array}$ \\
\hline $\begin{array}{l}\text { Academia \& } \\
\text { education }\end{array}$ & 7 & 5 & 3 & 15 & - & - & - & I \\
\hline Civil society & 11 & 12 & 7 & 30 & - & - & - & - \\
\hline Government & 13 & 16 & 23 & 52 & III & ॥ & III & ॥ \\
\hline Media & 0 & 2 & 1 & 3 & - & - & - & - \\
\hline Private sector & 1 & 6 & 4 & 11 & - & - & - & - \\
\hline $\begin{array}{l}\text { Regional/ } \\
\text { international } \\
\text { organisations }\end{array}$ & 10 & 12 & 9 & overlap & \multicolumn{4}{|c|}{ overlapping } \\
\hline $\begin{array}{l}\text { Resource } \\
\text { users }\end{array}$ & 4 & 9 & 5 & 18 & II & III & III & III \\
\hline $\begin{array}{l}\text { Traditional } \\
\text { authorities }\end{array}$ & 2 & 2 & 1 & 5 & I & II & I & - \\
\hline Total & 48 & 64 & 53 & - & - & - & - & - \\
\hline
\end{tabular}

One major challenge for decision makers in the region is the limited availability of information about the current situation and possible impacts on the provision of ecosystem services under different land and resource-use scenarios intensified by a generally low awareness for resources' values. Such information is needed for sound planning on land use and nature conservation in order to sustain ecosystems and hence people's livelihoods. To better link science to decision and policy making in practice, for TFO stakeholder involvement is essential in the research processes in order to set research priorities, integrate existing knowledge, adapt decision support to stakeholders' information needs and finally to increase chances that research outputs contribute to informed decision making and find their way into implementation (Seidel et al. 2012).

\section{The stakeholder landscape in the Okavango River Basin}

The selection of appropriate approaches for stakeholder involvement requires a prior identification of stakeholders that are relevant for the TFO research project. We define stakeholders as any group, organisation or individual, that may be affected by and/or have the ability to influence the problem at hand. A first step consisted in assessing the landscape of actors related to land use in the Okavango River Basin. The identification was mainly based on the expertise of TFO members who have in-depth knowledge of the stakeholder landscape, including local consultants and NGO members of the TFO team.

For each of the three countries a list of actors (individuals, groups and organisations) specifying their interest in ESS management and governance and the role they play in it has been compiled. The resulting list (with over 160 actors of potential relevance for TFO in total) was organised according to eight sector categories (Table 1). In a next step, the selection of stakeholders important for
TFO was based on the ranking of each actor (in terms of very weak, weak, moderate, strong and very strong) for the following criteria: (1) the stakeholder's potential impact on the management of ESS in the basin, (2) the stakeholder's potential to be affected by the provision of ESS in the basin, (3) the stakeholder's potential impact on the TFO project and (4) the stakeholder's potential to be affected by the project's outcome.

Similar patterns can be found in all three countries (Table 1): With reference to the first two prioritisation criteria, resource users, governmental bodies and traditional authorities have been rated most often to strongly or very strongly affect (1) and be affected by (2) ESS provision and management. The same three major stakeholder groups have,

\section{Box 1: The case of the scenario building process}

In the case of face-to-face interviews for the scenario building process, the stakeholder selection process revealed that stakeholders of four governance levels need to be distinguished and involved: the local core-site scale where impacts on resource use and management is manifested on the ground, the provincial or district level responsible for the implementation of policies influencing resource uses, the national level as sovereign decision-making power, as well as the transnational Okavango River Basin scale, where stakeholders impact on the transboundary use and governance of water, land and other natural assets. Figure 4 illustrates the final selection of stakeholders in Botswana selected for face-to-face interview purposes in the Scenario building ("TFO approaches for stakeholder involvement") process representing the four levels of governance. 


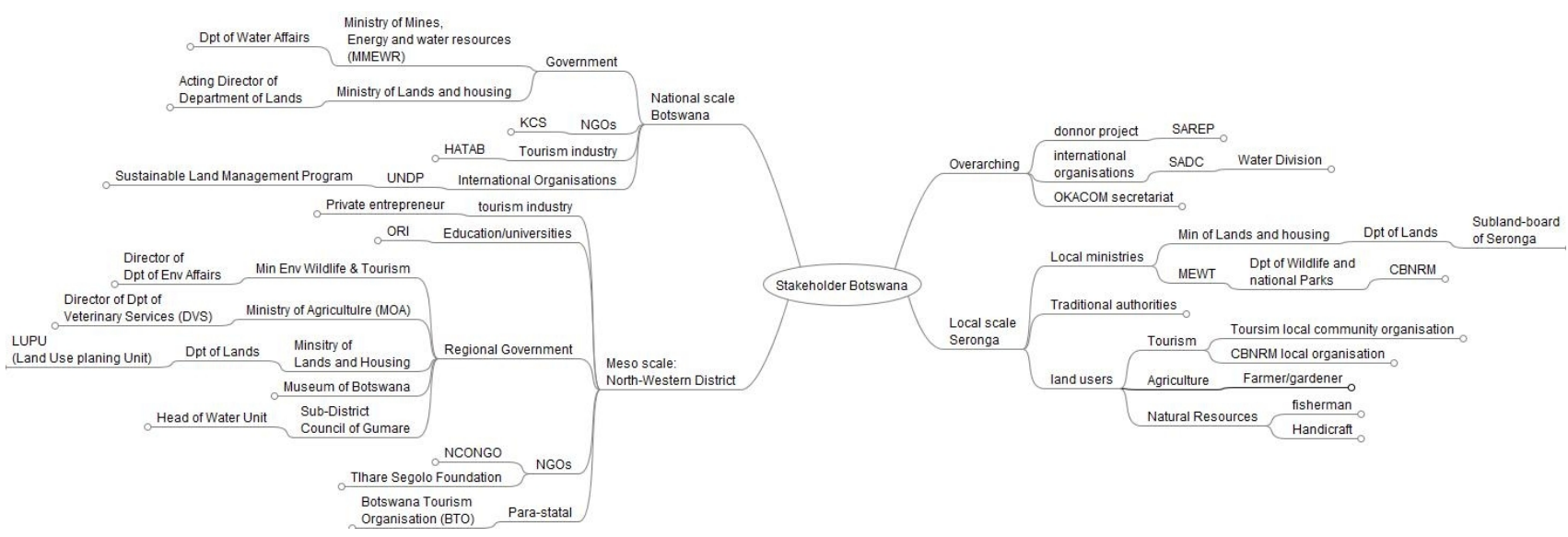

Fig. 4: Stakeholder landscape in the Okavango River Basin: the Botswana key stakeholder selection for face-to-face interviews on land use and change in the basin (scenario building context).

according to the analysis, the potentially strongest influence on the success of the TFO project (3). The project has the strongest potential impact on stakeholders (4) in the sector of resource users but also the government and the academic sector. Although the group of resource users is divers, the focus is mainly on local communities in the project areas as they are most affected by the provision of ESS. Additionally, regional and international organisations that operate in the Okavango region and that are in many cases identical organisations in the three countries are considered as generally important addressees for the progress of the project (Falk et al. 2012).

A last step consists in the selection of key stakeholders, which is specific to the respective project activity and its objective. The multi-scale analysis conducted in TFO also requires the identification of stakeholders at several scales of decision making from the local to the transboundary level (see Box 1 and Fig. 4). In practice, a discussion with local consultants and NGOS enables the identification of the country-specific stakeholder groups, institutions and structures and appropriate contact persons to address.

\section{TFO approaches for stakeholder involvement}

In this section we present from an academic perspective the approaches TFO has established to involve and interact with stakeholders outside academia in order to investigate and provide sound information for the management of the Okavango River Basin (Table 2). We highlight the level of involvement aimed at by each approach as well as its potential for mutual learning processes in TFO; more practical details on the implementation of the approaches within TFO are provided in boxes accordingly.

\section{Involvement as TFO project partner}

Although according to the stakeholder analysis civil society only plays a minor role concerning the use or management of ESS, they do have deep insight and knowledge on the social-ecological system and existing decision-making processes. Therefore, key stakeholders from civil society, but also governmental authorities have been part of the project from the beginning of its planning (see Box 2).

The cooperation as direct project partners refers to an empowerment of these stakeholders with equal status to the academic staff. Knowledge integration and expertise exchange take place through regular communication structures within TFO, joint research activities, thematic bilateral cooperation and consultation. The project benefits strongly from the facts that the partners are well connected to a broad range of stakeholders relevant to the phenomena of interest, have excellent knowledge about formal and informal communication channels and political processes and are well aware of potential or open conflicts. Due to their simultaneous involvement in practice as well as in science, they serve as important intermediaries between stakeholders and the scientific community, facilitating a process of better understanding concerning knowledge, needs, concerns, current processes and other aspects coming from the practice. Being part of other stakeholder processes these partners additionally act as multipliers for the continuous exchange of information on research activities and the dissemination and implementation of research findings in practice.

\section{The para-ecologists}

To facilitate and support the involvement of local farming communities in the project's core study sites, TFO employs three members of these rural communities as assistants, the paraecologists (see Box 3). This approach builds up on the positive experiences

\section{Box 2: TFO's project partners}

TFO's non-academic project partners are equal partners in the project and involved in all strategic and operational decisions, applied research and implementation tasks. Partners from the sector of civil society consist of NGOs: the Desert Research Foundation Namibia (DRFN) and Community Economic Development Project (CEDP) in Namibia as well as the Kalahari Conservation Society (KCS) in Botswana. They have long lasting experience in conducting work on sustainable natural resource management in local communities but are also strongly involved in national environmental policy development and implementation. Often they are key partners in other research and development initiatives in the Okavango region and thus important for the project's networking. Project partners from the governmental sector such as officials from the National Institute of Water Resources in Angola or the Ministry of Agriculture, Water and Forestry in Namibia, have very strong insight in political processes and visions as well as policy relevant research needs. 


\section{Box 3: The para-ecologist program}

The professional involvement of local actors with intimate knowledge of the ecosystem into research activities has been initiated more than 30 years ago (Basset et al. 2000, Janzen 2004) and is evolving ever since (e.g. Missouri Botanical Garden, Walters 2006). TFO full-time employs so-called para-ecologists that are members of the rural communities with extensive local knowledge that receive trainings by TFO members in order to assist research activities (Fig. 5). Besides supporting the organisation and implementation of research on-site, para-ecologists help to identify relevant stakeholders, translate in interviews and facilitate communication with other local stakeholders. Being rooted in the local community, speaking the local languages, and often having farming background themselves, para-ecologists have an intimate insight into the needs, values, aims and perspectives of the local land-user communities. Through their work and training, the para-ecologists are gaining deep insight into the needs, aims and perspectives of the scientific community respectively. Para-ecologists are therefore important facilitators to bridge the gap between the two communities. Additionally, living in the community, para-ecologists keep up the communication by being in continuous contact with researchers and local stakeholders during the progress of the projects.

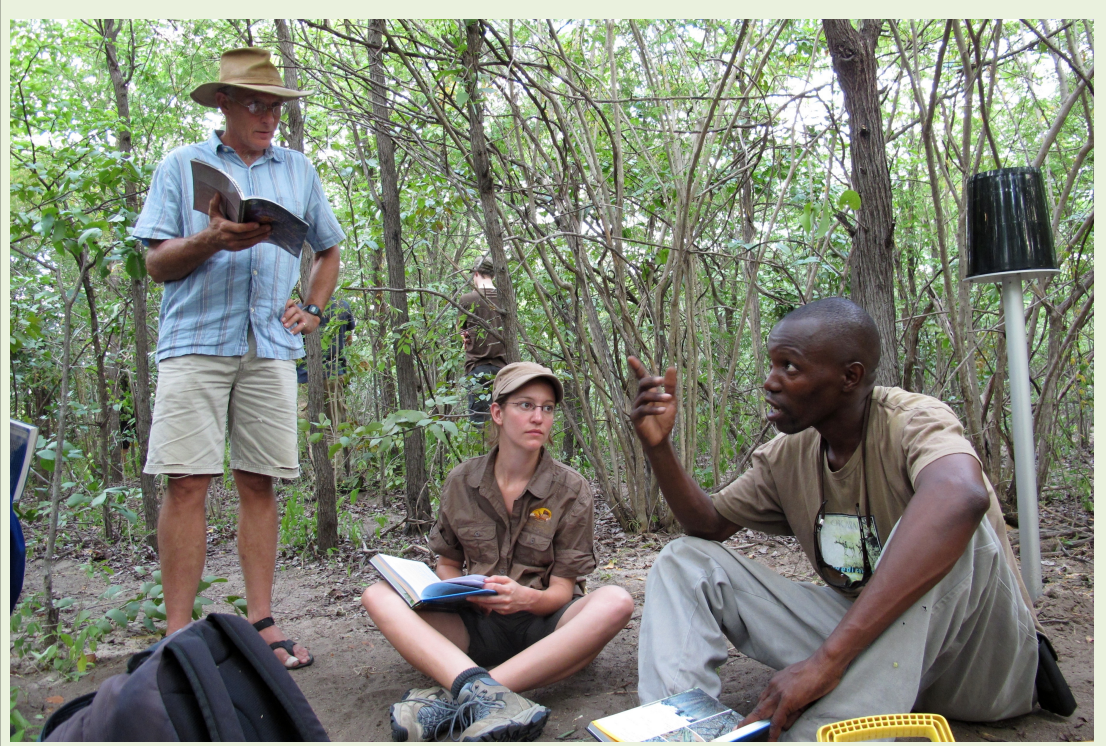

Fig. 5: Meshack Kwamovo, Para-ecologist in Seronga, Botswana, with TFO scientists in the field (Schmiedel, 2012).

made by TFO members on former research activities in Southern Africa ${ }^{1}$ (Schmiedel et al. 2010).

Para-ecologists serve as important intermediaries. They facilitate the communication between land user and scientists and enhance local stakeholder involvement mainly on the level of information and consultation but possibly up to collaboration - depending on the research activities. Being familiar with the local knowledge on the political, social and natural environment, its impact on the local land-use strategies and livelihoods, they make the information accessible and comprehensible for the researchers in terms of language and meaning. The other way around, they translate information and questions from the project for resource users in a way

\section{On-farm research}

The direct involvement of local resource users in order to develop, test and implement improved forms of land-use practices adapted to their needs and capacities seems inherent in the research project. An on-farm research approach has been chosen to experiment on forms of more sustainable cropping techniques (see Box 4 and Fig. 6).

The approach applies different intensities of stakeholder involvement. It includes mutual information transfer as well as consultation. At the same time, the approach allows farmers to become on-site researchers. Joint research activities and trials adapted by farmers to their needs can be considered as an empowerment in the research process on Conservation Agriculture. Although not all activities and adaptions by farmers were chosen in a way of highest scientific interest or relevance for researchers, scientists gained much deeper insight in local resource users' knowledge, abilities and needs. The ongoing exchange on farmers' practical experiences and researchers' accompanying analysis enables processes for knowledge coproduction and mutual learning.

\section{Participatory filmmaking}

Participatory filmmaking is an approach that aims to enable people to discuss their experiences, concerns and ideas by making films together, which then communicate the outcome of this process to wider audiences (Braden 1998, Lunch \& Lunch 2006). Participatory filmmaking within TFO is aimed at giving local stakeholders the opportunity to share their knowledge and concerns with the researchers and the wider public (see Box 5).

The films produced in collaboration with the local communities present topics and information that are potentially new and relevant to TFO researchers and general audiences alike. Instead of consulting stakeholders on topics defined by researchers, resource users get the chance to inform on issues of relevance for them. Filmmaking thus empowers the participants to become more equal partners in the research process (White 2003, Chamber 1994). Screenings and distribution of the resulting films to project partners and decision makers serve as a means of communicating local perspectives on social-ecological complexities in order to reveal knowledge and concerns that should be taken into consideration.

\section{Forums for Integrated Resource Management (FIRM)}

In the TFO project, various scientists are engaged in research activities on the ground, all with a need to interact with the local communities. By establishing FIRM, TFO facilitates the establishment of a platform for interaction between not only resource users and scientists, but also other local stakeholder and decision makers in order to address communities'

${ }^{1}$ See www.paraecologist.org [26.09.2013]. 


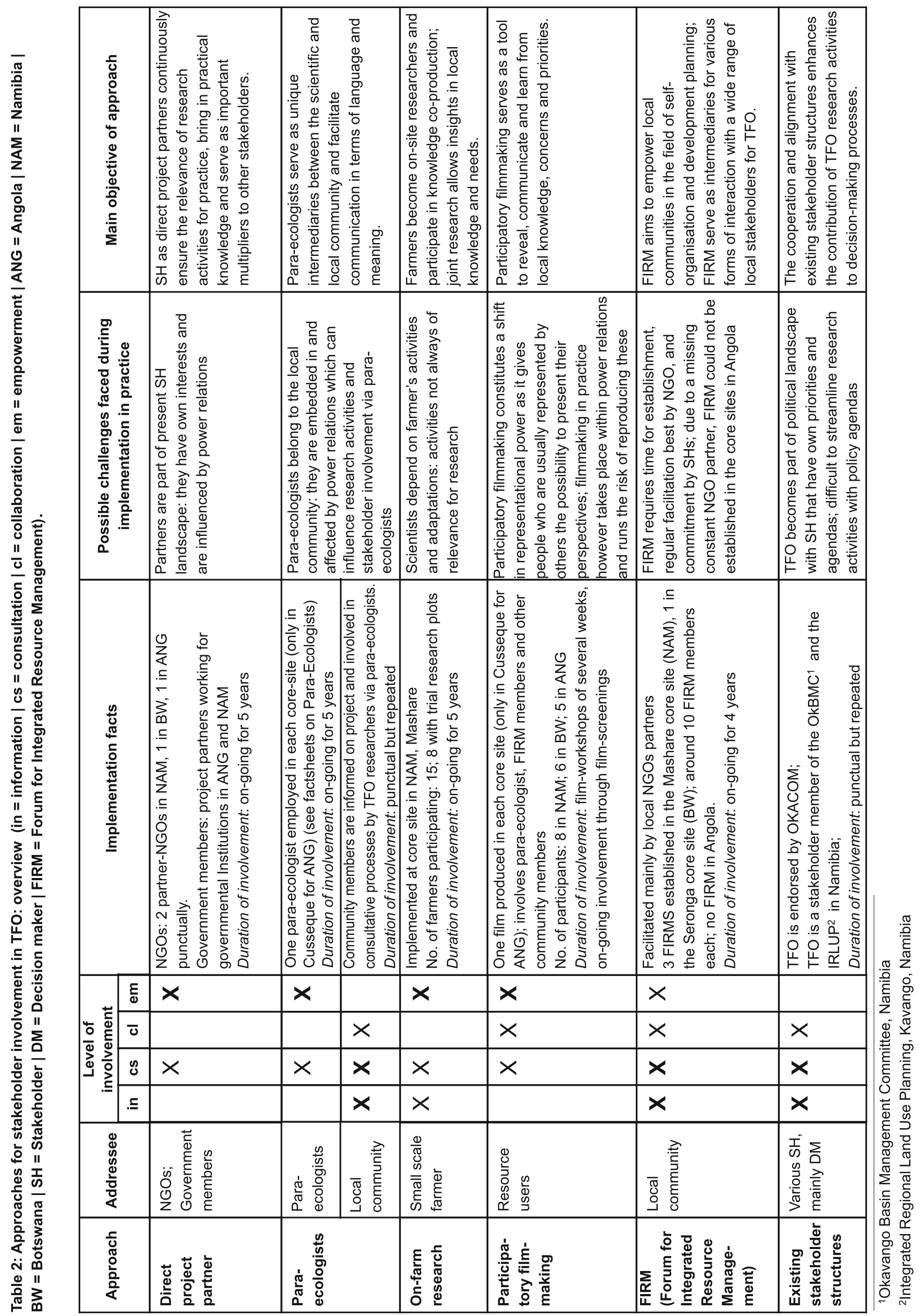




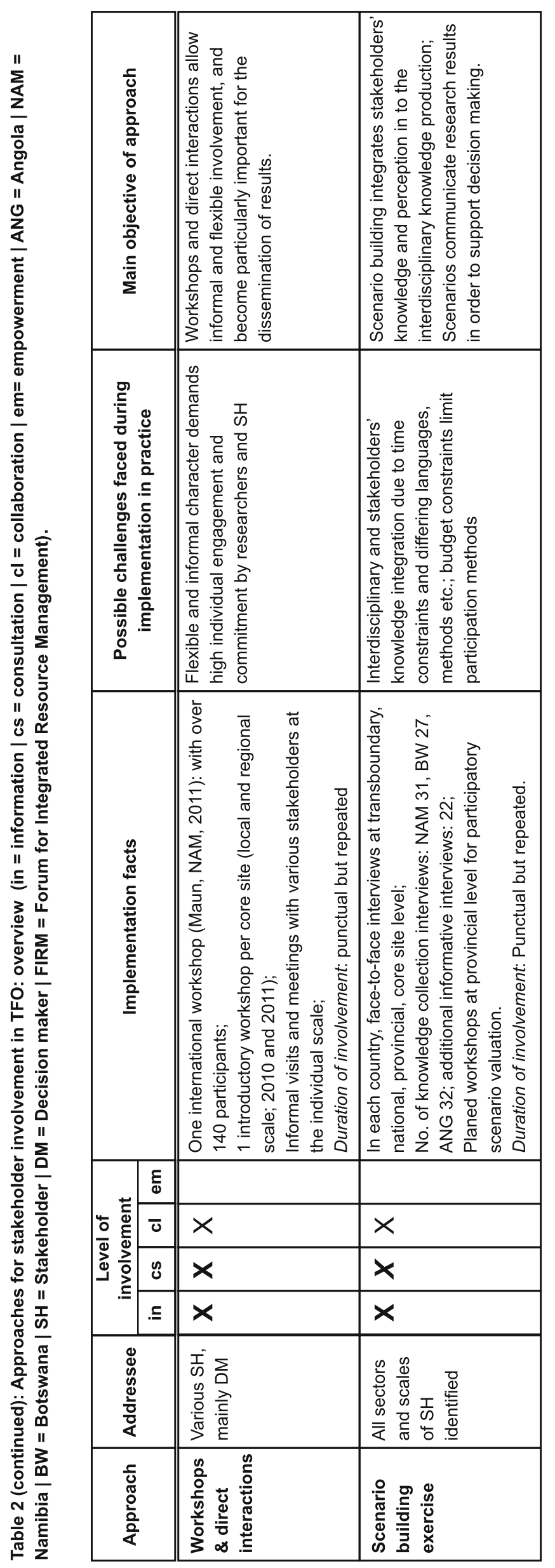




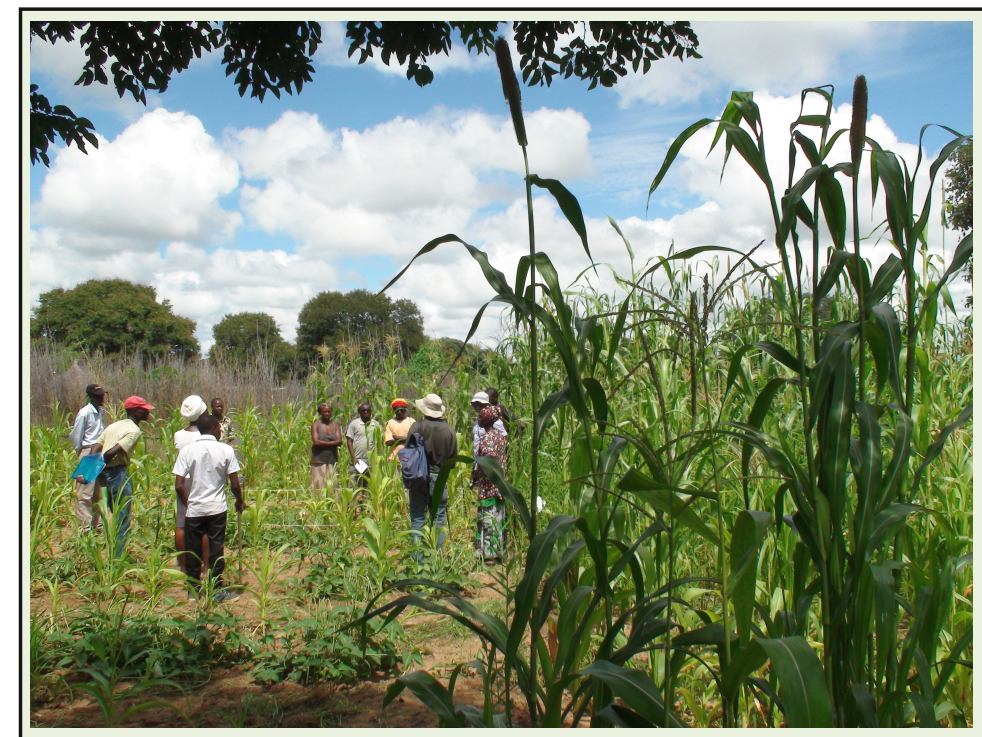

Box 4: Conservation Agriculture in Mashare

On-farm research is an approach to develop and test improved techniques in collaboration with local farmers on their fields and under farmers' regular conditions (Mutsaers \& Walker 1991). While the traditional agriculture (TA) practiced in the Okavango Basin comprises slash and burn with negative impacts on ESS, conservation agriculture (CA) has been identified as a possible solution for more sustainable cultivation with higher yields (Hobbs et al. 2008).

Together with TFO's partner NGO CEDP that has experience in training on $\mathrm{CA}$ techniques, farmers were selected to receive CA training and to participate in the research activities on CA in the Namibian TFO core-site of Mashare. Trial plots with CA and TA subplots for comparison with different soil amendments have been prepared on their fields with adaptations for cultivation to best suit the individual farmer's conditions. The different harvests of the farmers - who had already Fig. 6: Conservation Agriculture trial plots on a farmer's field (right), observed the differences in performance of crop, even if contrasted with Traditional Agriculture (left) in Mashare, Namibia unquantified - are analysed by scientists in terms of (Zimmermann, 2012) quantity and quality. Regular workshops and field days allowed farmers and scientists to learn from each other's experiences. In close exchange with the researchers they had the opportunity to jointly find solutions to obstacles.

challenges jointly (see Box 6).

When conducting research activities in the local communities, TFO members attend FIRM meetings to inform the community representatives about the project's progress and provide them with opportunities to influence the research by identifying issues that they seek solutions to, e.g. how to improve crop production and rangeland management. It also serves as a platform where scientists present and discuss their research plans, progress and findings which obliges scientists to translate their research into a format that is understandable and meaningful to the community representatives as well as other stakeholders involved (Fig. 8). Additionally, FIRM allows addressing not only the local community but all relevant service providers for the community that attend the meeting at the same time. Traditional authorities and governmental officials have been identified as the second prioritized group of stakeholders according to TFO's stakeholder analysis. They play a dominant role in local decision making and therefore have high influence on the management of ESS. These stakeholders are mainly involved through information and consultation.
However, through the FIRM approach, more intensive ways of involvement become possible.

\section{Engagement with existing stakeholder} structures and processes

With regard to the project's objective of supporting decision making, TFO specifically focuses on the engagement with the existing stakeholder structure OKACOM (see Box 7), a transboundary committee that acts as a priority key stakeholder in the Okavango River Basin. Because of its function as advisory body and being composed by national

\footnotetext{
Box 5: Participatory films in TFO

Film workshops with land users from different genders, age groups and social backgrounds have been implemented at TFO's core sites. Guided by the general theme of natural resource use, the participants of each film workshop conceived, directed and shot roughly 30 to 40 minute long films. They decided on the activities to be filmed, conducted the interviews, and operated the camera (Fig. 7).

"Our Life" (Gruber et al. 2011) from Mashare, Namibia, "The Secret of Our Environment" (Gruber et al. 2013) from Seronga, Botswana and „Honey“ (Antónia et al. 2013) from Cusseque, Angola are each the outcome of a collaboration between local stakeholders, TFO's para-ecologists with their unique intermediary position and an outside anthropologist. On the one hand, these films contain abundant information on natural resource use with distinctive local practices and perceptions. On the other hand, they are culturally significant statements, revealing local perspectives and concerns. Feedback screenings with other community members as well as at the other core sites contribute to cohesion within the respective community and offer potential for cross-cultural understanding and exchange. The dissemination of the films to decision makers serves as communication tool of local perceptions and needs.
}

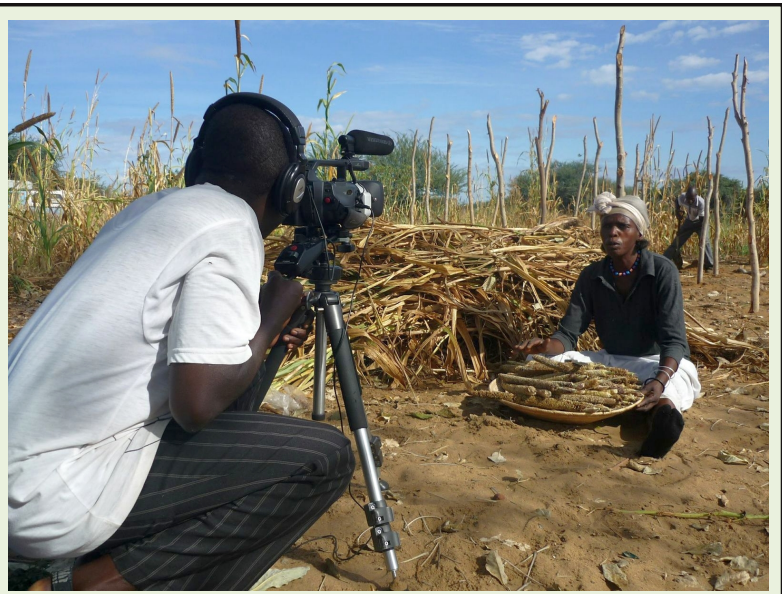

Fig. 7: Scene from the film-workshop in Mashare, Namibia (Gruber, 2011) 
governmental representatives, the involvement with OKACOM allows channelling communication to all relevant structure and unites within the three governments. OKACOM therefore acts as a catalyst for much broader involvement with stakeholders.

Similar to the engagement with OKACOM for the catchment level, the project is open to contribute also to national and district level policy processes. For instance, TFO is involved in a process for Integrated Regional Land Use Planning (IRLUP) in the Kavango regions in Namibia and participates at the workshops of the national Okavango Basin Management Committee (OkBMC) of Namibia.

Getting involved with existing structures and processes like OKACOM or the IRLUP causes changing roles of stakeholder involvement: while stakeholders now inform on their activities, project members get consulted by the stakeholders. Through the active participation in their processes though mostly in forms of workshops - different perceptions and hands-on experiences are exchanged and impulses for collaboration and mutual learning are initiated.

\section{Workshops and direct interactions}

Besides the cooperation with FIRM, OKACOM and other existing processes, workshops and direct contacts held by TFO contribute to a target-oriented and thematically focused involvement and informed decision making. So far, one TFO workshop on the transboundary level as well as one workshop in the core sites each was held in the beginning of the project (see Box 8). Although the workshops held mainly functioned as platform for information and consultation, emerging discussions and dialogues between all scientists and

\section{Box 6: The FIRM-approach}

The FIRM is an approach designed to enable rural communities to take a more active part in their own development (Kambatuku 2003) and has successfully been implemented in Namibia since 1998 (Kruger 2002). The FIRM is normally centred on an existing local Community Based Organisation (CBO) that takes the lead in organizing, planning and monitoring the community's development by identifying key challenges and, together with required stakeholders such as traditional authorities, government extension services, NGOs, as well as development or research projects all referred to as service providers - plan and implement solutions to these challenges. It becomes a communal platform for information exchange, and allows joint discussions on challenges and development goals leading to improved planning of activities and solution finding in the community as it addresses all service providers at the same time (Kambatuku 2003, Kruger et al. 2003, Manning \& Seely 2005).

FIRMs have been created in the project's core sites of Mashare, Namibia and Seronga, Botswana in collaboration with TFO's partner NGOs DRFN and KCS, who have experiences in communal development work. Within the FIRM the TFO project serves as one of the services providers, contributing to the development goals of the local communities by providing scientific findings that support decision making related to natural resource management. The FIRMs are important intermediaries between the TFO researchers and the local communities.

stakeholders participating led to two-way communication and paved the way for common understandings and mutual learning processes.

Apart from joint stakeholder workshops, individual stakeholders are involved through personal contacts. Depending on the scientist's disciplinary background or aim, links to relevant key stakeholders, have been established in order to allow regular exchange. Primarily on the basis of mutual information and consultation, leading to discussions on progress, results and further priorities of research activities, this form of involvement can support bridging the gap between researchers and practitioners in a manner to address the expressed needs by decision makers. Mutual exchanges give additionally the opportunity to discuss possible impacts of changes in the ecosystem and thus raise awareness on transboundary issues.

\section{Scenario building}

In the TFO project, the scenario building process (see Box 9) has several objectives. From a scientific point of view, it contributes (1) to the investigation of inter-scale dynamics (ecological and institutional) within in the Okavango River Basin: local, provincial, national, basin-wide; (2) to the analysis of trade-offs among ecosystem services and between conservation and human well-being; and (3) to the integration and synthesis of research results from several disciplines. From a transdisciplinary point of view, scenario building aims to integrate stakeholders' knowledge and perception to the scientific analysis. The scenario building process is used to communicate research results to stakeholders in a format that fosters the building of opinions about what type of land use stakeholders desire for the future and why (MEA 2010). In addition, by creating buy-in and interest for the

Table 3: Contributions of stakeholders in four steps of the scenario building process.

Step Explanation

Information sharing

Information, as far as possible spatially explicit, about projects and plans concerning land and resource use in the Okavango River Basin is collected and shared with the scenario team.

System Analysis

Identification of scenarios

Storyline cross-checking
Perceived drivers of change, land and resource-use indicators, well-being indicators, ecosystem services indicators, and current changes are collected through interviews and distributed to the scenario team as knowledge input during the system analysis.

Collected data on perceived most uncertain drivers and potential scenarios in terms of visions of stakeholders for land and resource use contribute to the identification of relevant scenarios.

After the storylines (narratives) describing different paths for land and resource use in the Okavango River Basin are drafted, they are sent to a selection of stakeholders who agreed to cross check the storylines in terms of plausibility and relevance. 


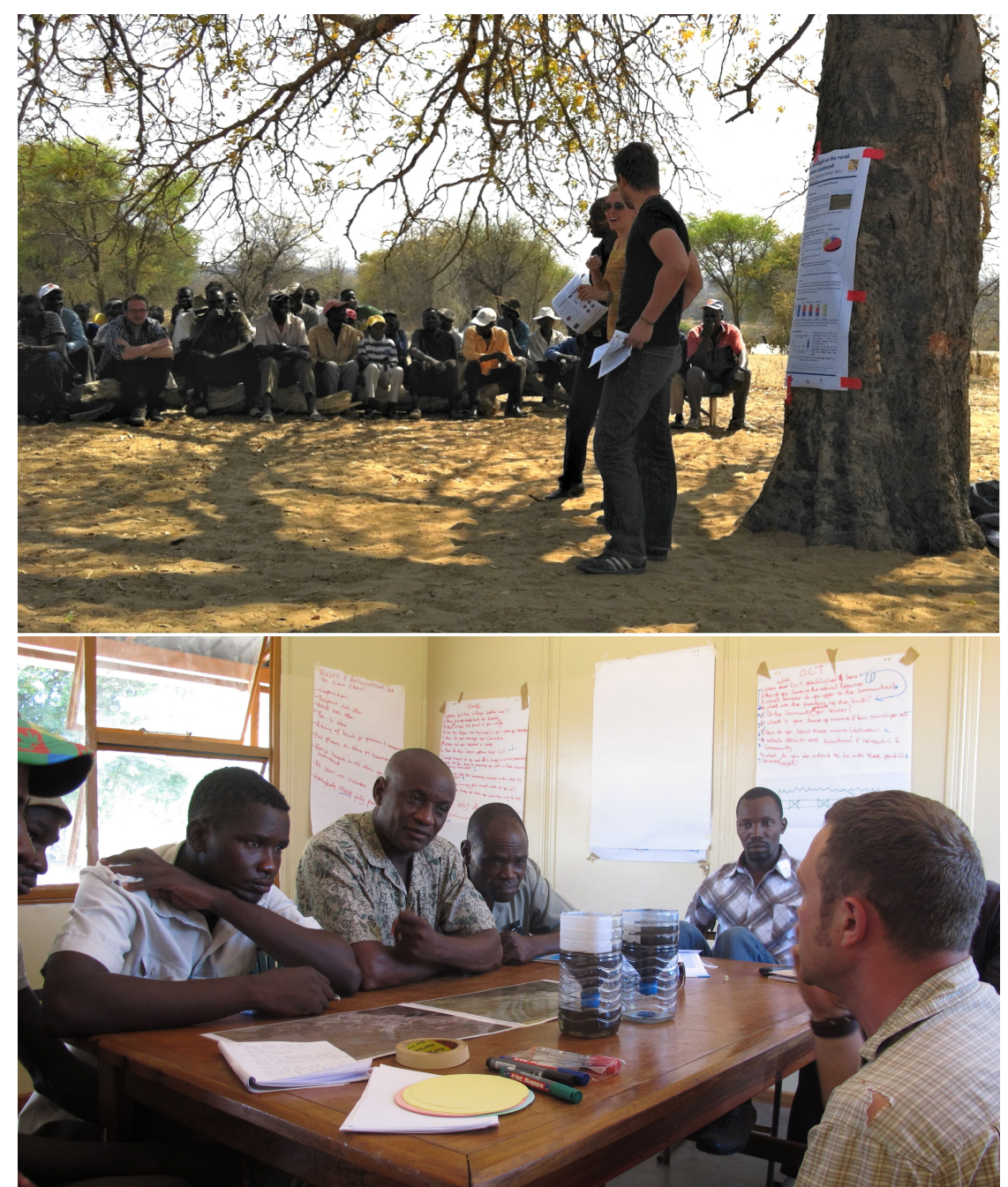

Fig. 8: Scientists reporting back to community at FIRM meeting in Mashare, Namibia (upper; Klintenberg, 2012) and discussing findings on soil quality with FIRM members in Seronga, Botswana (lower; Schmidt, 2013).

project (Cowling et al. 2008, Kok et al. 2011), the involvement of stakeholders in the scenario building process may enhance the chances of implementation of research results and of the research leading to a transformation (Lang et al. 2012) in the studied area.

The scenario exercise is conducted at two scales - catchment and core site (local). The involvement of stakeholders in this exercise covers four aspects (Table 3). The main involvement approach chosen was the conduction of face-to-face interviews in the field at all four levels in the three countries of the basin (for the value of face-to-face interviews see Patel et al. 2007; Fig. 9). A further involvement format is the cross-checking for plausibility of the scenario storylines by selected experts. A collaboration with
FIRM is envisaged to cross-check the local scenarios for relevant and plausibility in group with local land users. Finally, the scenarios will be presented and evaluated by stakeholders at the administrative local scale via a Multi-criteria Assessment setting. Thus, stakeholders are involved at the information and consultative level mostly.

\section{Opportunities and constraints: transdisciplinary challenges in context}

Although promising in its conception, integrating transdisciplinarity in the research practice is demanding (Lang et al. 2012). This section provides insights on some lessons learnt and constraints faced by applying the different approaches for stakeholder involvement in TFO and place these in a more general context of challenges faced in the practice of transdisciplinarity.

\section{Project partners and power relations}

The involvement of stakeholders as direct partners in the research team as well as the employment of para-ecologists emerged as enormously valuable in the transdisciplinary research process due to their local insights. A feedback survey on the involvement of para-ecologists underlined how highly the scientists valued this support ${ }^{2}$. However, being rooted in the local communities, paraecologists are influenced by and embedded in power relations which researchers need to keep in mind and reflect upon in order to avoid influences on research activities biased by external interests on the one hand as well as to ensure a more objective involvement of and communication with stakeholders by para-ecologists on the other. Similar concerns exist regarding the non-

\footnotetext{
Box 7: OKACOM: The Permanent Okavango River Basin Water Commission

Based on the OKACOM Agreement signed in 1994 by the three countries Angola, Botswana and Namibia, the commission's role is to act as an advisory body to the contracting countries with the objective to manage the water resources of the Okavango River in a coordinated and integrated way based on equitable allocation, sustainable utilisation, sound environmental management and the sharing of benefits. The OKACOM structure, consisting of high-level governmental representatives of the riparian countries, is considered as the main focal point to address statutory policy makers in the Okavango region by the TFO project (OKACOM 2011, Pinheiro 2003).

TFO has carefully elaborated in which areas and ways its research can support the implementation of OKACOM's Strategic Action Plan (SAP). This way, TFO intends to provide relevant research findings contributing to the research priorities identified by the three riparian countries. The project reports frequently to OKACOM on its progress during their regular meetings and communicates on a bilateral level for exchange. All data collected and created by TFO will be provided to OKACOM and other associated stakeholders in the form of a web-based, integrated data base (OBIS - Okavango Basin Information System; see Kralisch et al. this issue).
} 
academic project partners. They are embedded in the stakeholder landscape and involved in various on-going processes, representing their own interests. At the same time, these close linkages are of high value for the project as they help to connect research with practice.

\section{The transdisciplinary open character versus restrictive funding schemes}

Addressing on the one hand the requirements and topics predefined by a funding agency as well as stakeholders' research priorities and real-world concerns on the other hand is not always easy to reconcile. A consequent transdisciplinary research approach would require substantial funding for stakeholder consultation already during the development of research proposals (Pohl 2010). In the case of TFO, already existing contacts and a workshop held in Luanda, Angola, one year prior to the project start, allowed consulting stakeholders in informal ways during the project's conception. While research projects should ideally start with consultations on stakeholders' concerns and knowledge in order to formulate research questions, this rarely is the case in practice due to financial and time limitations (Spangenberg 2011, Pohl 2010). In the case of the involvement of local scale stakeholders for instance, the establishment of FIRM and shooting of participatory films prior to the start of the project would have been of advantage to better consider stakeholders' views. Yet, in practice, the demand from funding agencies for strict time frames and preconceived research agendas make such a flexible approach difficult.

\section{Mismatching schedules and agendas}

Similar challenges become apparent when engaging with existing stakeholder processes. OKACOM, as a strategic key stakeholder (Siew \& Döll 2012) for TFO, consists of high-level politicians with own schedules and agendas that TFO, as an externally funded research project, has to align with. For a research project like TFO with predefined operation plans and

\section{Box 8: TFO's workshops}

A three-day workshop was organised by TFO in Maun, Botswana in September 2011, addressing mainly national stakeholders from politics with the attendance of the majority of the TFO team. Besides presenting the project, its objectives and first results, several open discussions and working groups enabled dialogues on the different viewpoints, needs, concerns and expectations regarding TFO research.

To introduce the project on the core sites of the TFO project, three introductory workshops have been organised involving relevant representatives from the communities but also from the regional level, such as traditional authorities, regional public authorities, and civil society operating in the respective region. The main aim of these workshops was to first inform about the project, to receive support and permission for research activities as well as to learn about priorities of stakeholders related to ESS and resource management. In addition, it was the first opportunity for stakeholders and scientists with differing disciplinary background to exchange their perspectives of the phenomenon under research.

budgets, it is not always easy to streamline its activities and attend and contribute to stakeholders' meetings that are often announced only at short notice. This challenge similarly refers to the engagement with FIRM. TFO just serves as one of many service providers to them and researchers need to align on FIRM's schedules and priorities that do not always match their own.

\section{Stakeholders' expectations and interests}

Interviews with stakeholders on their perception of TFO and their involvement showed that decision makers are highly interested in research outcomes, while the demand to be actively involved in activities is rather $l \mathrm{w}^{3}$. This underlines that an empowerment of stakeholders should not be considered as the ultimate form of involvement reasoned by its highest level of intensity. The appropriate level of involvement depends on the case, itself conditional on the commitment of all stakeholders including the researchers and by the existence of enabling governance structures (Collins \& Ison 2009, Krütli et al. 2010, Brandt et al. 2013). However, the engagement of researchers with stakeholders also raises interests and expectations towards the project among the later. At the local scale, stakeholders tend to mistake TFO for a development project and develop high expectations with regard to solving their everyday life problems and bringing in 'development'. The engagement with existing stakeholder structures like OKACOM leads to a changed conception from an involvement of to the involvement with stakeholders, or rather becoming involved as stakeholder. Becoming part of the stakeholder landscape, TFO faces the challenge to maintain its objective scientific role and to not become a pawn of existing power interests. At the same time, TFO researchers need to reflect on their role they play as stakeholder in this landscape and on the way they shape it accordingly.

\section{Transdisciplinary research and personal commitment}

As adaptations in the academic system to encourage transdisciplinary research are still rare, transdisciplinary endeavours are only little rewarded for a scientific career (Jahn 2012, Enengel et al. 2012). Involving stakeholders in researcher is, however, consuming in terms of time, resources and efforts (Maasen \& Lieven 2006) and the increasing demands on researchers can lead to overburdening (Pohl \& Hirsch Hadorn 2007). The interviews with project partners and stakeholders showed that this constraint does not only apply for the researchers, but also for stakeholders, whose interest in becoming involved is often taken for granted. Furthermore, the interaction between different disciplines, cultures, and languages results in multiple social and communication challenges (Lang et al. 2012, Jahn 2008). The success of transdisciplinary research is therefore much depending on the commitment of scientists and stakeholders to invest into the process (Jahn et al. 2012). In the case of stakeholder involvement through workshops and personal contacts for instance, knowledge exchange may

\footnotetext{
${ }^{2}$ A questionnaire with open-ended questions was conducted via e-mail within the whole TFO team in 2013 (Schmiedel, unpublished). ${ }^{3} \mathrm{~A}$ series of qualitative interviews with African project partners and stakeholders representing the local, provincial, national and transboundary level was conducted in Botswana and Namibia in 2013 (Schmidt, unpublished).
} 


\section{Box 9: The Scenario building approach in TFO}

Scenarios can be defined as plausible and simplified descriptions of how the future may unfold, based on a coherent and internally consistent set of assumptions about key driving forces, their relationships, and their implications for ecosystems (MEA 2010). The TFO scenarios are explorative (Kok et al. 2011), consisting of forwardlooking stories exploring different possible future land uses guided by the focal question: How will land use, ecosystem services and well-being change in time from now to 2030 at the basin scale, and at the local scale in each case study? The scenarios are majorly developed by TFO scientists, however they additionally offer a platform for the integration of practical knowledge, collected via interviews with 90 identified stakeholders at all scales of decision making on land use in the Okavango River Basin and in each country of the basin. The inclusion of stakeholder knowledge increases the relevance as well as the accuracy of the scenarios (MEA 2010). Further, the scenarios and their impact on the environment and well-being in the basin will be evaluated with stakeholders in the form of workshops.

potentially lead to processes of mutual learning and knowledge integration, however, the commitment to take the statements named into consideration in the own research process depends mostly on individual engagement.

\section{Discussion}

The presentation of the different approaches for stakeholder involvement in TFO shows that stakeholders are involved in order to learn from existing knowledge and local perceptions of landuse related processes, to reconcile research activities with the priorities and desired decision support of target groups as well as to foster the recognition and ownership of the research and its outcomes. This section aims to discuss how the different approaches contribute to addressing the TFO goals for stakeholder involvement as well as their relevance for the creation of the three knowledge types in transdisciplinary research, namely system, target and transformation knowledge. As a result, we provide insights on achievements and shortcomings of stakeholder involvement and finally point to possibilities of adaptation for the remainder of the project as well as for the design of future projects.

\section{TFO's approaches for stakeholder involvement: levels of involvement and the contributions to the generation of system, target and transformation knowledge}

With regard to the overview given in Table 2, it is apparent that each of the approaches can serve different levels of stakeholder involvement. However, a clear emphasis of stakeholder stakeholders' perception. ecosystem services (Domptail, 2013). involvement on the level of information as well as consultation becomes evident. Stakeholder involvement on the local level facilitated by para-ecologists and FIRM as well as stakeholder involvement through direct contacts, workshops, and the engagement with existing structures were mainly used to inform on the project and its progress, as well as to collect stakeholders' knowledge on the land-use system, hence to create system knowledge. In the context of the scenario interviews, consultative processes mainly focus on the generation of system knowledge and provide, to a lesser extent, first insights on target knowledge, that is, how the future ought to be from the

Participatory filmmaking and on-farm research have the clear objective to empower stakeholders through involvement. Both refer to participatory

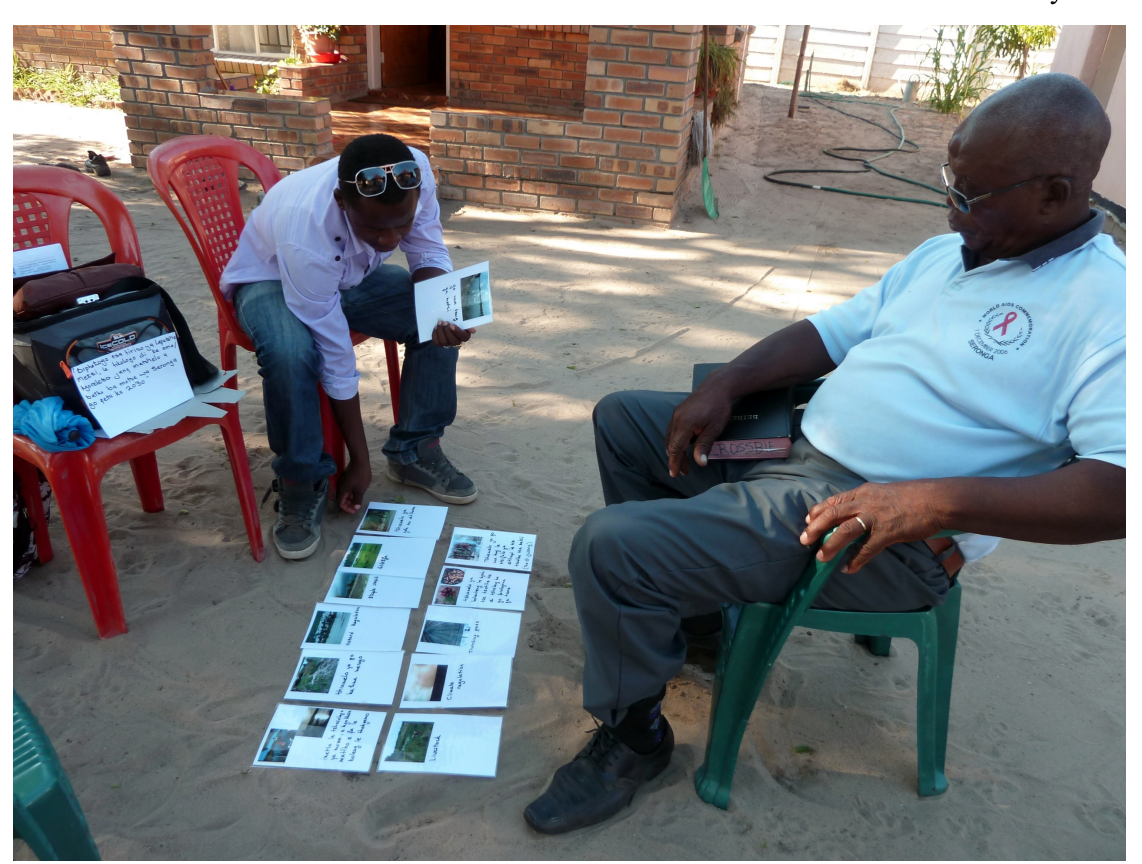

Fig. 9: Stakeholder interview at the local level (Seronga, Botswana): ranking of key

research approaches, in which stakeholders are fully involved in the whole cycle. By identifying restrictions of the current farming system, defining objectives for improved practices and finally developing and testing innovations, on-farm research implies processes of co-production on system, target as well as transformation knowledge between researchers and farmers. Participatory filmmaking mostly reveals knowledge on the system and gives some impressions on stakeholders' vision for the target state.

Finally, involvement on the level of empowerment also refers to stakeholders who are directly involved as direct project partners as well as the paraecologists. Being involved in research activities, these stakeholders incorporate their practical and local knowledge and experiences for the generation of mainly system knowledge. However, as some of these partners such as representatives from the governmental sector or civil society are also involved in processes on the development of strategies or solutions for improved land use, contributions to target and transformation knowledge are also possible.

\section{Meeting TFO's aims of stakeholder involvement: achievements, gaps and recommendations}

Our results show a focus on interaction processes taking place first at the local level, second for information purposes, and third for the creation of system 
knowledge. The following sections detail the achievements and shortcomings and finally give recommendations to meet TFO's aims of stakeholder involvement.

\section{Strengths and achievements}

The presentation of the approaches demonstrates the high diversity of instruments for stakeholder involvement that have been established in the project. The approaches are designed in a flexible way that allows selecting and combining the instruments, depending on the aim of the respective research activity. The FIRM approach and participatory filmmaking has explicitly been applied to identify local research priorities. On the higher political level this happened mainly through face-to-face interviews in the scenario building context as well as through direct contacts established like in the case of OKACOM. All approaches help to learn from stakeholders' knowledge and perception on the system state and give first insight on target knowledge. Direct interactions with OKACOM and the engagement in already existing stakeholder processes like in the case of the Integrated Regional Land Use Planning (IRLUP) in Namibia fosters the role of research in contributing to decision-making processes. Good structures for the distribution and discussion of information have been established on the local level via the FIRM approach and the para-ecologist program.

\section{Gaps and shortcoming}

Although workshops and direct contacts with stakeholders with decision makers enable reciprocal information sharing, they not necessarily lead to processes of mutual learning and knowledge coproduction. Recalling the conceptual idea of transdisciplinary research, processes of mutual learning are a prerequisite for knowledge integration. The lack of more institutionalised structures for stakeholder involvement that foster mutual learning processes in the project on higher governance levels can be explained by a (too) divers stakeholder landscape within three countries and the related expenses in terms of costs, time and effort. This reasons the engagement with OKACOM as focal addressee of high-level decision makers and multiplier of mutual learning processes.

Additionally, an imbalance regarding the knowledge types towards system knowledge exists. Transdisciplinarity in concept does not imply that all three knowledge types need to be considered to the same extent within the same research question. However, the interdependencies between the three types of knowledge and the general aim of transdisciplinary research for solution-oriented knowledge need to be taken into account (Pohl \& Hirsch Hadorn 2007). While the better understanding of the social-ecological system of the Okavango Basin is the main focus of the project, the creation of knowledge on the target state as well as on transformation strategies cannot be disregarded in order to support decision making.

\section{Recommendations for a follow-up of a dynamic stakeholder involvement}

The challenges faced in doing transdisciplinary research emphasize the need for a flexible and dynamic approach for stakeholder involvement as proposed by Stauffacher et al. (2008). The flexible application and adaptation of the instruments allows stakeholder involvement in the most effective way in order to provide the wanted scientific support for decision making in the remaining project phase. A closer look at our analysis allows us highlighting key target groups and suggesting approaches appropriate for the corresponding involvement.

With regard to stakeholders from highlevel governance structures, stakeholder involvement and communication of results first targets existing transboundary and national river basin committees (such as OKACOM for the basin and OkBMC in Namibia) as well as individual key members from respective ministries and departments identified at various governance levels. In addition, current processes and activities of land use planning are important addressees for information and data exchange and can serve as a platform to learn on target and transformation knowledge.

Furthermore, key individual researchers, consultants and representatives from the civil society that are involved in policy-making processes in the Okavango River Basin are an important target for the use and dissemination of TFO research results. They can act as receiver and magnifier of TFO information, as lobbyer among decision makers and may integrate TFO research findings in future projects. Similarly, TFO's partner NGOs can play a fundamental role in the dissemination of results among decision makers due to their higher legitimacy, their long-term involvement and lobbying capacities.

Besides direct interactions with key stakeholders, workshops and round tables provide the scene to present and discuss research results as well as the opportunity to initiate the production of target and transformation knowledge amongst a wider range of target groups. As workshops are cost intensive and time consuming, cooperation with existing stakeholder platforms to increase synergies and reduce transaction costs could be valuable alternatives.

At the local scale, -especially among farmer communities, $\neg$ creative forms of communication allow local resource users to understand scientific findings. Paraecologists have a key role in supporting TFO researchers to prepare, share and discuss research results in a relevant and appropriate manner and serve as multiplier for the dissemination of results among farmer community and local administration. In addition, a strong involvement of FIRM allows scientists to discuss findings with local serviceproviders and farmer and to initiate joint reflections on target and transformation knowledge.

Finally, scenarios form an integral part of the communication strategy. They will be communicated through workshops primarily to the attention of already interviewed local, regional (and national) government members, regional and national NGOs and experts. Scenarios have a strong informative power with their presentation of research results in a concise and integrated format. Confronted with stories and their impact on the environment and well-being, stakeholders shall be able to build an opinion about different potential future land use paths; in other words, it should generate target knowledge among stakeholders.

\footnotetext{
${ }^{4}$ E.g. the Integrated Regional Land Use Planning (IRLUP) in Kavango, Namibia; the Okavango Land Use Planning by GABHIC (Gabinete para Administração da Hidrográfia da Bacia do Rio Kunene; The Cunene River Basin Authority, under the Ministry of Energy and Water (MEA) in Angola), the Okavango Delta Management Plan (ODMP) for the Delta in Botswana, the GIS-based Land Use Conflict Information System (LUCIS) developed by SAREP for the basin and piloted in Seronga, among others.
} 


\section{Concluding remarks}

The case of the TFO project shows, how interesting and valuable, but at the same time complex and absorbing a transdisciplinary research process is. Transdisciplinarity is a concept in progress. Being promising in its conception to solve complex real-world problems, transdisciplinary research faces several challenges in practice (Lang et al. 2012). The changing role of science in society and the increasing social accountability, demanding for a societal usefulness of scientific results while facing rigid structures, bears the risk of too high expectations and demands on research (Maasen \& Lieven 2006). Approaching these expectations requires structural changes (Jahn et al. 2012) as well as learning processes on doing transdisciplinarity within the academic world but also within society. This also includes the aspect of reflection, meaning a critical self-assessment of the individual and disciplinary role when creating socially robust knowledge (Spangenberg 2011). By presenting the approaches used to involve stakeholders in the research process and by discussing the experiences made in the TFO project, we contribute to a learning process on transdisciplinary research and aim to trigger processes of reflection on the respective role of scientists and stakeholders.

\section{Acknowledgements}

The design of the paper was conceived by L.S., S.D. and T.F. S.D. contributed in particular to the design and the writing of the analytical part of this paper. T.F. strongly contributed with his expertise on the TFO project and stakeholder landscape in the Okavango River Basin. The contributions for the specific approaches have been guided by S.D. for the scenario-building process, by M.G. for the participatory filmmaking, by P.K. and T.F. for the FIRM approach, by U.S. for the para-ecologist program, and by I.Z. for the on-farm research approach. The article was primarily written up by L.S. with major contributions by S.D. and T.F. and was critically revised by M.G., P.K., U.S. and I.Z. Special thanks to Jan Wehberg for designing an illustrative map of the Okavango Basin.

The TFO project is funded by the German Ministry of Education and Research (BMBF) (promotion numbers 01 LL 0912 A, 01 LL 0912 E, 01 LL 0912
F, 01 LL 0912 G) .Special thanks to all project partners and stakeholders who participated in the interviews reflecting on TFO's transdisciplinary research approach. We also thank all our colleagues from the TFO project and the various stakeholders in Angola, Namibia and Botswana for their engagement in and support of this transdisciplinary research project. The constructive comments and valuable suggestions of the two reviewers helped to improve the quality of a previous version of this article.

\section{References}

Antónia, A., Gruber, M., Hilario, M.S., Job, H. B., Jose, F., Quintas, E. (2013): Honey. - 39 mins. Angola, Germany: University of Bremen.

Arnstein, S. (1969): A Ladder of Citizen Participation. - Journal of the American Institute of Planners 35(4): 216-224. CrossRef

Basset, Y., Novotny, V., Miller, S.E., Pyle, R. (2000): Quantifying biodiversity: Experience with parataxonomists and digital photography in Papua New Guinea and Guyana. - BioScience 50(10): 899-908.

Bergmann, M., Brohmann, B., Hoffmann, E., Loibl, C., Rehaag, R., Schramm, E., Voß, J.-P. (2005): Quality Criteria for Transdisciplinary Research. A Guide for the Formative Evaluation of Research Projects. ISOE Studientexte, No. 13. Frankfurt am Main.

Braden, S. (1998): Video for Development. A Casebook from Vietnam. - Oxford: Oxfam.

Brandt, P., Ernst, A., Gralla, F., Luedritz, C., Lang, D., Newig, J., Reinert, F., Abson, D., von Wehrden, H. (2013): A review of transdisciplinary research in sustainability science. - Ecological Economics 92: 1-15. CrossRef

Chambers, R. (1994): The Origins and Practice of Participatory Rural Appraisal. - World Development 22(7): 953-969. CrossRef

Collins, K., Ison, R. (2009): Jumping off Arnstein's ladder: social learning as a new policy paradigm for climate change adaptation. - Environmental Policy and Governance 19(6): 358-373. CrossRef

Cooke, B., Kothari, U. [Eds.] (2004): Participation: The New Tyranny? London: Zed Books.

Cowling, R., Egoh, B., Knight, A., O'Farrell, P., Reyers, B., Rouget, M., Roux, D.ll, Welz, A., Wilhelm-Rechman, A. (2008): An operational model for mainstreaming ecosystem services for implementation. - Proc Natl Acad Sci USA 105(8): 9483-9488.

Dubielzig, F.; Schaltegger, S. (2004):
Methoden transdisziplinärer Forschung und Lehre. Ein zusammenfassender Überblick. - Lüneburg: CSM.

Enengel, B., Muhar, A., Penker, M., Freyer, B., Drlik, S., Ritter, F. (2012): Co-production of knowledge in transdisciplinary doctoral theses on landscape development. An analysis of actor roles and knowledge types in different research phases. - Landscape and Urban Planning 105(1-2): 106-117. CrossRef

Falk, T., Klintenberg, P., Monggae, F., Schmidt, L. (2012): Stakeholder analysis for the region of the Okavango catchment. - In: Seidel, H., Gröngröft, A., Pröpper, M. [Eds.] (2012): A Conceptual Framework for "The future Okavango Project" (TFO). Research on Ecosystem Services and Landuse in the Okavango Basin. - TFO Online Working Paper 1/2012: 62-80.

Gruber, M., Hamutenya, C.S., Immanuel, T., Kapumburu, V.N., Kwandu, S., Mashare, J., Mukuya, R., Simata, A., Sinkumba, R., Zangata, C. (2011): Liparu Lyetu - Our Life. - 32 mins. Namibia, Germany: University of Bremen.

Gruber, M., Kwamovo, M., Marungu, G., Moeze, C., Mofundikwa, R., Moruti, K., Mozumbi, M., Wamana, G. (2013): The Secret of Our Environment. - 34 mins. Botswana, Germany: University of Bremen.

Häberli, R., Grossenbacher-Mansuy, W. (1998): Transdisziplinarität zwischen Förderung und Überforderung. Erkenntnisse aus dem SPP Umwelt. GAIA 7(3): 196-213.

Hansen, M. C., Potapov, P.V., Moore, R., Hancher, M., Turubanova, S.A., Tyukavina, A., Thau, D., Stehman, S.V., Goetz, S.J., Loveland, T.R., Kommareddy, A. Egorov, A. Chini, L., Justice, C.O., Townshend, J.R.G. (2013): High-Resolution Global Maps of 21st-Century Forest Cover Change. Science 342: 850-583. CrossRef

Hirsch Hadorn, G., Bradley, D., Pohl, C., Rist, S., Wiesmann, U. (2006): Implications of transdisciplinarity for sustainability research. - Ecological Economics 60(1): 119-128. CrossRef

Hobbs P.R., Sayre K., Gupta R. (2008): The role of conservation agriculture in sustainable agriculture. - Philosophical Transactions of the Royal Society 363 : 543-555. CrossRef

Jahn, T. (2008): Transdisziplinarität in der Forschungspraxis. - In: Bergmann M., Schramm, E. (Eds.): Transdisziplinäre Forschung. Integrative Forschungsprozesse verstehen und bewerten. 21-37. Frankfurt/Main: Campus Verlag.

Jahn, T., Bergmann, M., Keil, F. (2012): Transdisciplinarity: Between mainstreaming and marginalization. Ecological Economics 79: 1-10. 


\section{CrossRe}

Janzen D. (2004): Setting up tropical biodiversity for conservation through non-damaging use: participation by parataxonomists. - Journal of Applied Ecology 41: 181-187. CrossRef

Kambatuku, J.R. [Ed.] (2003): FIRM, the forum for integrated resource management: putting communities at the centre of their own development process. - NAPCOD, Windhoek.

Kgathi, D.L., Kniveton, D., Ringrose, S., Turton, A.R., Vanderpost, C.H.M., Lundqviyt, J., Seely, M. (2006): The Okavango; a river supporting its people, environment and economic development. - Journal of Hydrology 331(1-2): 3-17. CrossRef

Klein, J. T. (2008): Integration in der interund transdisziplinären Forschung. - In: Bergmann, M., Schramm E. [Eds.]: Transdisziplinäre Forschung. Integrative Forschungsprozesse verstehen und bewerten. 94-116. Frankfurt/Main: Campus Verlag.

Klein, J. T., Grossenbacher-Mansuy, W., Häberli, R., Bill, A., Scholz, R., Welti, M. [Eds.] (2001): Transdisciplinarity: Joint problem solving among science, technology, and society: an effective way for managing complexity. - Basel: Birkhauser Verlag. CrossRef

Kok K., van Vliet M., Bärlund I., Dubel A., Sendzimir J. (2011): Combining participative backcasting and exploratory scenario development: Experiences from the SCENES project. - Technological Forecasting \& Social Change 78: 835-851. CrossRef

Kralisch, S., Zander, F., Flügel, W.-A. (2013): OBIS - a Data and Information Management System for the Okavango Basin. - Biodiversity \& Ecology 5: 213-220. CrossRef

Kruger, A.S. (2002): \#Khoadi/Hoas Conservancy: Part 1: Livestock numbers, stocking rates and rangeland condition. - Desert Research Foundation of Namibia, Namibia's Programme to Combat Desertification, Windhoek.

Kruger, A.S., Gaseb, N., Klintenberg, P., Seely, M.K., W., W. (2003): Towards community-driven natural resource management in Namibia: The FIRM example. - In: Allsopp, N., Palmer, A.R., Milton, S.J., Kirkman, K.P., Kerley, G.I.H., Hurt, C.R., Brown, C.J. [Editors]: VIIth International Rangelands Congress, Durban, South Africa, 1757-1759.

Krütli, P., Stauffacher, M., Fleler, T., Scholz, R. (2010): Functional dynamic public participation in technological decision making: site selection processes of nuclear waste repositories. - Journal of Risk Research 13(7): 861-875. CrossRef

Lang, D., Wiek, A., Bergmann, M., Stauffacher, M., Martens, P., Moll, P.,
Swilling, M., Thomas, C. (2012): Transdisciplinary research in sustainability science: practice, principles, and challenges. Sustainanbility Science 7(Supplement 1): $25-43$. CrossRef

Lunch, N., Lunch, C. (2006): Insight into Participatory Video. A Handbook for the Field. - Oxford: Insightshare.

Maasen, S., Lieven, O. (2006): Transdisciplinarity: a new mode of governing science? - Science and Public Policy 33(6): 399-410.

Manning, N., Seely, M.K. (2005): Forum for Integrated Resource Management (FIRM) in Ephemeral Basins: Putting communities at the centre of the basin management process. - Physics and Chemistry of the Earth 30 : 886-893. CrossRef

Mbaiwa, J. (2004): Causes and possible solutions to water resource conflicts in the Okavango River Basin: The case of Angola, Namibia and Botswana. Physics and Chemistry of the Earth 29(15-18): 1319-1326. CrossRef

MEA - Millenium Ecosystem Assessment (2005): Ecosystems and Well-being: current state and trends. Island Press. Millenium Ecosystem Assessment.

MEA 2010: Henrichs T., Zurek M., Eickhaut B., Kok K., Raudsepp-Hearne C., Ribeiro T., van Vuuren D., Volkery A. (2010). Chapter 5: Scenario Development and analysis for Forwardlooking ecosystem Assessments. In: MEA: Ecosystems and Human Wellbeing: A Manual for Assessment Practitioners. http://www.unepwcmc.org/ecosystems-and-humanwellbeing_553.html

Mendelsohn, J., el Obeid, S. (2004): Okavango River. The flow of a lifeline. Windhoek.

Mobjörk, M. (2010): Consulting versus participatory transdisciplinarity: A refined classification of transdisciplinary research. - Futures 42(8): 866-873. CrossRef

Mogalle, M. (2001): Management transdisziplinärer Forschungsprozesse. - Basel: Birkhäuser.

Moll, P., Zander, U. (2006): Managing the Interface. From Knowledge to Action in Global Change and Sustainability Science. - München: Oekom.

Mutsaers, H.J.W., Walker, P. (1991) [Eds]: On-farm research in theory and practice. Proceedings of a workshop on design and analysis of on-farm trials. 27 Feb. to 3 Mar. 1989. IITA, Ibadan, Nigeria.

OKACOM (2011): Cubango-Okavango River Basin Transboundary Diagnostic Analysis. - Maun, Botswana.

Patel, M., Kok, K., Dale, R. (2007): Participatory scenario construction in land use analysis: An insight into the experiences created by stakeholder involvement in the Northern
Mediterranean. - Land Use Policy 24(3): 546-561. CrossRef

Pinheiro, I., Gabaake, G., Heyns, P. (2003): Co-operation in the Okavamgo river basin: The OKACOM perspective. - In: Turton, A., Ashton, P. Cloete, E. [Eds]: Transboundary Rivers, Sovereignty and Development: Hydropolitical Drivers in the Okavango River Basin. 105-118. African Water Issues Research Unit and Green Cross International, Pretoria, South Africa and Geneva, Switzerland.

Pohl, C. (2010). From transdisciplinarity to transdisciplinary research.

Transdisciplinary Journal of Engineering \& Science 1(1): 74-83.

Pohl, C., Hirsch Hadorn, G. (2007): Principles for Designing Transdisciplinary Research. - Munich: Oekom.

Pröpper, M., Falk, F., Domptail, S.E., Große, L.M., Kowalski, B. (2013): Partly subsistent household economies and modern consumerism in the Namibian Kavango: Assets, income, expenditure and socio-economic stratification. Biodiversity \& Ecology 5: 379-391. CrossRef

Reyers, B., Roux, D., O'farrell, P. (2010): Can ecosystem services lead ecology on a transdisciplinary pathway? Environmental Conservation 37(04): 501-511. CrossRef

Roux, D., Rogers, K., Biggs, H., Ashton, P., Sergeant, A. (2006): Bridging the science-management divide: moving from unidirectional knowledge transfer to knowledge interfacing and sharing. Ecology and Society 11(1): art4.

Röder, A., Stellmes, M., Domptail, S.E., Eschenbach, A., Finckh, M., Gröngröft, A., Helmschrot, J., Pröpper, M., Schneibel, A., Stoffels, J. (2013): Cumulative effects of policy and management actions on ecosystem services. Challenges and methodological approaches in The Future Okavango project. - Biodiversity \& Ecology 5: 167-183.

Schmiedel U., Mtuleni V.S., Christiaan R.A., Isaacks R.S., Kotze D., Lot M.J., Mukuya R.S., Pieters W., Swartbooi J., Swartbooi S. (2010): The BIOTA paraecologist programme towards capacity development and knowledge exchange. - In: Schmiedel U., Jürgens, N. [Eds.]: Biodiversity in southern Africa. Volume 2: Patterns and processes at regional scale. 319-325. Göttingen, Windhoek: Klaus Hess Publishers.

Schneibel, A., Stellmes, M., Revermann, R., Finckh, M. (2013): Agricultural expansion during the post-civil war period in southern Angola based on multi-temporal Landsat data. Biodiversity \& Ecology 5: 311-319. CrossRef

Scholz, R. (2011): Environmental Literacy in Science and Society: From 
Knowledge to Decisions. - Cambridge: Cambridge University Press.

Scholz, R.; Tietje, O. (2002): Embedded case study methods. Integrating quantitative and qualitative knowledge. - Thousand Oaks: Sage Publications. CrossRef

Seidel, H., Gröngröft, A., Pröpper, M. [Eds.] (2012): A Conceptual Framework for "The future Okavango Project" (TFO). Research on Ecosystem Services and Landuse in the Okavango Basin. - TFO Online Working Paper $1 / 2012$.

Siew, T.-F., Döll, P. (2012): Transdisciplinary research for supporting the integration of ecosystem services into land and water management in the Tarim River Basin, Xinjiang, China. - Journal of Arid Land 4(2): 196-210. $\underline{\text { rossRef }}$

Spangenberg, J. (2011): Sustainability science: a review, an analysis and some empirical lessons. - Environmental Conservation 38(3): 275-287. CrossRef

Stauffacher, M., Flüeler, T., Krütli, P., Scholz, R. (2008): Analytic and Dynamic Approach to Collaboration: A Transdisciplinary Case Study on Sustainable Landscape Development in a Swiss Prealpine Region - Systemic Practice and Action Research 21(6): 409-422. CrossRef

Stellmes, M., Frantz, D., Finckh, M., Revermann, R. (2013). Okavango Basin - Earth Observation. Biodiversity \& Ecology 5: 23-27. CrossRef

TEEB (2010): The Economics of Ecosystems and Biodiversity: Mainstreaming the Economics of Nature: A synthesis of the approach, conclusions and recommendations of TEEB.

Tress, B., Tress, G., Décamps, H., d'Hauteserre, A.-M. (2006): Bridging human and natural sciences in landscape research. - Landscape and Urban Planning 57: 137-141. CrossRef

Turton, A., Ashton, P. Cloete, E. [Eds] (2003): Transboundary Rivers, Sovereignty and Development: Hydropolitical Drivers in the Okavango River Basin. African Water Issues Research Unit and Green Cross International, Pretoria, South Africa and Geneva, Switzerland.

Walters G. (2006): Conserving plant diversity in the Massif Du Chaillu of Gabon: Linking conservation and parataxonomy - report on parataxonomy training in Waka National Park. Missouri Botanical Garden.

Weber, T. (2013). Okavango Basin Climate. - Biodiversity \& Ecology 5: 15-17. CrossRef

White, S. [Ed.] (2003): Participatory Video: Images That Transform and Empower. London: Sage Publications.

\section{Affiliations}

Laura Schmidt* (laura.schmidt@unihamburg.de), Ute Schmiedel (ute.schmiedel@uni-hamburg.de), Biodiversity, Evolution and Ecology of Plants (BEE), Biocentre Klein Flottbek and Botanical Garden, University of Hamburg

Ohnhorststr. 18

22609 Hamburg, GERMANY

Stephanie Domptail,

(stephanie.domptail@agrar.unigiessen.de)

Institute for Agricultural Policy and

Market Research, University of Giessen,

Senckenbergstrasse 3

35390 Giessen, GERMANY

Thomas Falk(falkt@)staff.uni-

marburg.de)

Institute for Co-operation in Developing

Countries, University of Marburg

Am Plan 2

35037 Marburg, GERMANY

Martin Gruber, (gruber@uni-bremen),

Department for Anthropology and

Cultural Research

University of Bremen

Enrique-Schmidt-Str. 7

28359 Bremen, GERMANY

Patrik Klintenberg

(patrik.klintenberg@mdh.se)

School of Business, Society \&

Engineering, Mälardalen University

Högskoleplan 1

72123 Västerås, SWEDEN

Ibo Zimmermann,

(izimmermann@polytechnic.edu.na)

Agriculture Department, Polytechnic of

Namibia,

P/Bag 13388

Windhoek, NAMIBIA

*Corresponding author 